\title{
Az Egészségipari Támogatási Program kedvezményezett vállalkozásai a világjárvány és a negyedik ipari forradalom idején
}

\author{
Beneficiary enterprises of the Health Industry Support Program \\ during the global pandemic and the fourth industrial revolution \\ Dr. Kiss Éva, Dr. Uzzoli Annamária \\ ELKH Csillagászati és Földtudományi Kutatóközpont Földrajztudományi Intézet
}

Az egészségipar sokrétüen járul hozzá az egészségügyi ellátórendszer müködéséhez, ezért a fejlesztése mindig is nemzetgazdasági prioritás volt, ami azonban a 2020-ban kirobbant világjárvány következtében még sürgetőbbé vált. A tanulmány célja, hogy bemutassa egyrészt az Egészségipari Támogatási Programból részesült egészségipari vállalkozások fontosabb jellemzőit, másrészt, hogy a támogatások hogyan segítették az egészségipar alkalmazkodását az új kihíváshoz a negyedik ipari forradalom idején.

Health industry contributes to the operation of the national health care system in many ways thus its development has always been a national economic priority. However, due to the global pandemic burst in 2020 it has become more urgent. The main aim of this paper is on the one hand to demonstrate the major characteristics of the health industrial enterprises supported by Health Industry Support Program, and on the other hand, to reveal how supports promote the adjustment of health industry to the new challenges at the time of the fourth industrial revolution.

\section{BEVEZETÉS}

A COVID-19 világjárvány a negyedik ipari forradalom idején jelent meg és számos kihívást eredményezett a gazdaságban és a társadalomban is. A járvány visszaszorítására, illetve mérséklésére hozott különböző intézkedések az iparban is éreztették hatásukat. Többek között felgyorsították azokat a folyamatokat (automatizáció, digitalizáció, robotizáció), amelyek a negyedik ipari forradalmat fémjelzik, és aminek most még az elején vagyunk [1]. Bár a negyedik ipari forradalom gyökerei az ezredfordulóra nyúlnak vissza, jelentősebb előrehaladás ezen a téren csak az elmúlt évtizedben következett be, amit az utóbbi időben a járvány is sürgetett. A húzóerőit kilenc új technológia (autonóm robotok, kiterjesztett valóság, szimuláció, vertikális/horizontális integráció, dolgok Internete, Felhő, Big data, additív gyártás, kiberbiztonság) adja, amelyeket együttesen Ipar 4.0-ként említenek 2011 óta [2].

Az is nyilvánvalóvá vált, hogy azok a gazdasági vállalkozások lehetnek a legnagyobb nyertesei az újabb forradalmi változásoknak és tehetnek szert komoly versenyelőnyre, amelyek képesek az új technológiákat alkalmazni és az azok- hoz kapcsolódó fejlesztéseket minél hamarabb megvalósítani. A járványhelyzetben főleg az egészségipari vállalkozások múszaki-technológiai fejlesztése kapott kitüntetett figyelmet, hiszen a tevékenységük felértékelődött és a gyors alkalmazkodásuk rendkívül fontossá vált. Ehhez nyújt bizonyos fokig segítséget a 2020 nyarán meghirdetett Egészségipari Támogatási Program (ETP). A program vissza nem térítendő támogatásairól azért született döntés, hogy segítségével csökkenjen a gazdaság sérülékenysége és fokozódjon világpiaci versenyképessége, hogy javuljon az önellátási képesség, és hogy elősegítse a népesség egészségének védelmét.

A tanulmány alapvető célja a koronavírus-járvánnyal összefüggő, az Egészségipari Támogatási Programból támogatott hazai egészségipari fejlesztések értékelése. Bemutatjuk, hogy a járvány következtében milyen egészségipari beruházások, fejlesztések történtek az egészségiparban megjelenő többnyire ipari termelőtevékenységet folytató vállalkozásoknál, és hogy melyek ez utóbbiak főbb jellemzői (cégméret, tevékenység, földrajzi fekvés stb.). A kérdések megválaszolásához a kormányzati hírportál Egészségipari Támogatási Programról szóló közleményei és a támogatásban részesült vállalkozásokról rendelkezésre állt cégadatok és egyéb információk szolgáltak kiindulási alapként. A támogatott vállalkozások adatait a Creditonline cégadatbázisából gyűjtöttük ki, majd ezt követően az összeállított vállalati adatbázist különböző szempontok szerint elemeztük. A vizsgálati eredmények jó támpontot nyújtanak az Egészségipari Támogatási Program gyakorlati jelentőségének és a közreműködő vállalkozások jobb megismeréséhez.

\section{AZ EGÉSZSÉGIPAR FOGALMA ÉS KAPCSOLATA AZ IPARRAL}

Az egészségipar fogalma valójában egy gyűjtőfogalom, aminek tartalma folyamatosan változik, fejlődik. Nincs egységes definíciója. Szűkebb és tágabb értelemben egyaránt használják. Általában magába foglalja - közvetve vagy közvetlenül - az egészség megőrzésére, helyreállítására, az egészségi állapot stabilizálására, az egészség által meghatározott életminőség javítására irányuló szolgáltatásokat, valamint a termékelőállítási, illetve az ezek kifejlesztését és alkalmazását elősegítő szervezési, oktatási, kutatási-fejlesztési, kommunikációs tevékenységeket [3]. Az egészségipari tevékenységek és szolgáltatások komplex módon járulnak hozzá az egészséggazdaság működéséhez. 
Az egészségiparhoz tágabb értelemben direkt és indirekt módon köthető összes tevékenység és szolgáltatás az alábbi csoportokba osztható be [4]:

- Az egészségügyi ellátórendszer szolgáltatásai: a prevenciótól kezdve a gyógyításon át a rehabilitációig.

- Az egészségügyi ellátórendszer müködését támogató szakmai szolgáltatások és egyéb szakmai beszállítói tevékenységek: pl. gyógyszergyártás, orvosi műszerek előállítása, egészségügyi informatika, finanszírozási és biztosítási mechanizmusok stb.

- Az egészségügyi ellátórendszer müködését támogató nem szakmai szolgáltatások és egyéb nem szakmai beszállítói tevékenység: pl. orvosi ruházat eloállítása, energiaellátás, hulladékkezelés, élelmiszerellátás stb.

- Életmódipar tevékenységei és szolgáltatásai: egészségfejlesztésre épülő szolgáltatások pl. szépségipar, egészségturizmus, életmód-tanácsadás, rekreációs és szabadidősport, valamint táplálékkiegészítők stb. gyártása.

Szűkebb értelemben azonban az egészségipar fogalma alatt csak azokat a tevékenységeket értjük, amelyek tényleges ipari termelést jelentenek. Másképpen mondva az egészségipar az egészségipari termékek iparban való előállítását célzó tevékenységek összessége a fogyasztói igények, szükségletek kielégítése érdekében [5]. Tulajdonképpen témaválasztásunk szempontjából is ez a megközelítés az irányadó. Így az egészségipar ezen szegmensét helyezzük vizsgálódásaink középpontjába a továbbiakban.

A gazdaság szekunder szektorán, az iparon belül vannak olyan ágazatok, amelyek teljes mértékben (pl. gyógyszeripar, orvosi műszergyártás) az egészségiparhoz sorolhatók és akadnak olyanok is (pl. textilipar), amelyek csak egy-egy termékük (pl. egészségügyi munkaruházat gyártása) révén kapcsolódnak ahhoz. Ennélfogva az előbbiek nemzetgazdasági jelentőségét viszonylag pontosan meg lehet határozni, ellenben az utóbbiakról ez kevésbé mondható el a sajátos ágazaton belüli helyzetükből fakadóan.

A múszaki-technikai fejlődés és az ipar, s ezáltal az egészségipar fejlődése szorosan összefonódik. A történelem során a korábbi ipari forradalmak újitásai nagymértékben elősegítették az ipar egészének és egyes ágazatainak is a fejlődését. A kedvező hatásaik többek között a gyógyászatban is megmutatkoztak (pl. korszerübb diagnosztikai eszközökkel csökkenhet a halálozások száma, növekedhet az élettartam), de a gazdaság egészében is előbb-utóbb érvényesültek. A mostani ipari forradalom vívmányai, az Ipar 4.0 technológiák szintén forradalmasítják az ipari termelést, ami majd az egészségiparban is egyre határozottabban fog megnyilvánulni az elkövetkezendő években. Kétségtelen az is, hogy az egészségiparhoz kapcsolódó vállalkozások ugyancsak anyagi helyzetüktől és egyéb adottságaiktól függően differenciáltan reagálnak az újabb ipari forradalom és a közelmúltban megjelent globális járvány okozta kihívásokra. A különféle támogatások és pályázati források viszont nagymértékben hozzájárulhatnak a müszaki-technológiai fejlődésükhöz, továbbá ahhoz, hogy relatíve gyorsabban alkalmazkodjanak az új körülményekhez, és hogy ezek alapján maradéktalanul eleget tudjanak tenni küldetésüknek.

\section{EGÉSZSÉGIPARI TÁMOGATÁSI PROGRAM}

Az egészségipar technológiai alapú fejlesztése stratégiai jelentőségü, ezért az elmúlt évtizedben is kiemelt szerepet kapott a különféle egészségfejlesztési tervekben [6]. A Semmelweis Terv (2011) az egészségipar jelentőségét és GDP-termelő potenciálját hangsúlyozta Magyarország versenyképességének növelésében és az egészségügy, mint húzóágazat megerősítésében. Tulajdonképpen kitörési pontként jelent meg az egészségturizmus fejlesztése és az egészségiparba történő beruházások rendszerszintű támogatása is. A Semmelweis Terv cselekvési terve az Egészséges Magyarország 2014-2020 - Egészségügyi Ágazati Stratégia (2015) lényegében megerősítette a hazai Egészségipar Program fontosságát és olyan komplex programként definiálta, ami az egészséget szolgáló termelő és szolgáltató iparágakat kapcsolja rendszerbe [7]. Az egészségipari fejlesztések egyik nagy csoportját alkotja a stratégiai tervezés szintjén a digitális eszközök és szolgáltatások fejlesztése, ami végső soron az egészségügy digitalizációját is segíti. A DEFS - Digitális Egészségipar-fejlesztési Stratégia (2017) a Digitális Jólét Program 2.0 része. A stratégiában megfogalmazott cél az, hogy az egészségügyben alkalmazott digitális megoldások minél nagyobb mértékben járuljanak hozzá a társadalom egészségnyereségéhez [8]. A negyedik ipari forradalom új technológiái (pl. felhőszolgáltatás) már az egészségügyben is megfigyelhetők [9] és egyre szélesebb körben használatosak, amit az egészségügyi dolgozók körében a digitális technológiák használatáról végzett felmérés tapasztalatai is megerősítenek [10].

Az elmúlt év azonban a járványhelyzet miatt bizonyos fokig fordulatot hozott a korábbi egészségipari fejlesztési elképzelésekben, azok újragondolása és átalakítása vált szükségessé. Ez tükröződött a múlt esztendőben bevezetett Egészségipari Támogatási Program pályázati kiírásában is, ahol egy 13 pontból álló szempontrendszerben foglalták össze azt, hogy milyen célt kell szolgálnia, illetve milyen feltételeknek kell megfelelnie a támogatott egészségipari cégnek. Ez a program elsősorban az egészségipar termelőtevékenységet folytató vállalkozásainak támogatását célozta különböző módokon. Ezek között pl. a hazai egészségügyi termék gyártás megerősítése, a gyógyszerhiányok mértékének csökkentése vagy pl. a munkahelyek megörzése és az Ipar 4.0 megoldások alkalmazásának ösztönzése szerepelt. A legkisebb támogatható projektméretnek - a kiírás szerint el kellett érnie a 400 millió forintot. A beruházásoknál az elszámolható költségek legalább felét gépekre, berendezések beszerzésére kell fordítani, ellenben az infrastrukturális és ingatlanberuházások aránya az elszámolható költségek legfeljebb 50 százaléka lehet. Az egészségipari támogatások a járványügyi helyzetre való gyors reagálás mellett a gazdaságpolitikai terveknek is fontos részét képezik abból a szempontból, hogy már a járvány utáni helyzetre is felkészítik a 
magyar gazdaságot az egészségügyi gyártókapacitások fejlesztése révén. Az Egészségipari Támogatási Programot 50 milliárd forintos kerettel írták ki, amelyekhez a vállalkozások saját forrásait is hozzászámítva közel 65 milliárd forint összértékű beruházás valósulhat meg 2021 első félévében.

Az ETP pályázati felhívására 2020 második felében, két szakaszban - novemberben és decemberben - kaphattak állami támogatást a magyar vállalkozások. A támogatások a beruházások meghatározott hányadára terjedhettek ki. A tervezett beruházásnak max. 80\%-át fedezheti a támogatás a koronavírus-járvánnyal kapcsolatos termékek előállítása esetében, amelyeket hat hónap alatt kell megvalósítani. Az egyéb, egészségipari kapacitást növelő beruházások költségeinek 50-80\%-át biztosíthatta a támogatás. Mindezen támogatások által a jövőben csökken az ország kiszolgáltatottsága az egészségügyi védőeszközök ellátása terén, hisz a gumikesztyűk, maszkok, gyógyszerek, fertőtlenítők, lélegeztetőgépek, orvosi műszerek gyártásában növekedni fognak a termelési kapacitások. Emellett az Egészségipari Támogatási Program a hazai gyógyszer- és gyógyászati eszközgyártás fejlesztését is célul tűzte a gyártóhelyek számának emelésével és hatékonyságuk növelésével.

Az Egészségipari Támogatási Programban ismertté vált nyertes vállalkozások száma 19 volt 2020 végén, így a részletes elemzés tárgyát a továbbiakban ezek képezik. Közülük a legtöbben termékgyártásra és/vagy termékfejlesztésre nyertek támogatást, míg a többiek vagy komplex fejlesztésre, vagy csak telephely-fejlesztésre. Mivel ezen beruházások megvalósítása 2021 első félévéhez kapcsolódik, ezért azok eredményességéről, tényleges jelentőségéről most még nincsenek ismereteink. Ezekről legkorábban csak az év második részében várhatók információk.

Azt is fontos megemlíteni, hogy 2021 márciusában az Egészségipari Támogatási Program keretében újabb pályázat került meghirdetésre 23 milliárd forintos keretösszeggel mikro-, kis- és középvállalkozásoknak, hogy egészségipari termékek gyártásával összefüggő fejlesztéseket vagy kapacitásbővítő beruházásokat valósítsanak meg. Az azóta eltelt idő rövidsége miatt azonban csak feltételezhető, hogy az ezen pályázat nyertes cégeinek ismérvei tovább fogják árnyalni majd az ETP-ből első alkalommal nyert vállalkozásokról az alábbiakban bemutatott főbb tapasztalatokat.

\section{AZ EGÉSZSÉGIPARI VÁLLALKOZÁSOK FONTOSABB JELLEMZŐI}

Az Egészségipari Támogatási Program nyertes vállalkozásainak több mint a felét az ezredforduló előtt alapították és csak 15\%-uknak - összesen három vállalkozásnak - az alapítása köthető az elmúlt évtizedhez. Következésképp, hoszszabb múlttal rendelkező, tartósan (jól) működő vállalkozások, ami a támogatás sikere szempontjából nem elhanyagolható tényező.

A vállalkozások méretstruktúrája igen széles skálán mozgott: a mikrovállalkozástól a kis-, közép- és nagyvállalatig minden kategória előfordult körükben. A legnagyobb tábort az 50-249 fős középvállalkozások képezték. A legkisebb létszámot, öt főt a budaörsi székhelyű PREMET Kft. mondhatta a magáénak, ahol pl. 3D nyomtatással készítenek orvosi eszközöket. A legnagyobb létszámú (401 fős) a tiszapüspöki Kall Ingredients Kft., ahol etil-alkoholt állítanak elő fertőtlenítőszerek alapanyagaként.

Az Ipar 4.0 technológiák alkalmazásában és terjedésében releváns szerepe van a vállalkozások méretének. Külföldi és hazai kutatási eredmények is igazolták, hogy általában a nagyobb méretű cégek azok, amelyeknél előrehaladottabb a digitális transzformáció. Ezeknek a cégeknek a pénzügyi helyzete teszi ugyanis lehetővé a leginkább, hogy nagy összegeket fektessenek az új technológiákba, illetve a termelés modernizálásába és a termékek fejlesztésébe [11-13]. Ezek tükrében igen valószínű, hogy a 19 vállalkozásból is a nagyobbakban gyakoribb a technikai újdonságok használata, amit a tetemes összegủ támogatások is elősegíthetnek.

A vállalkozások közel $80 \%$-a a fő tevékenységének a TEÁOR besorolása szerint az iparhoz tartozott, három a kereskedelemhez és egy a „Szakmai, tudományos, müszaki tevékenység” kategóriába. Az utóbbi négy vállalkozás köré-

\begin{tabular}{|c|c|c|c|}
\hline \multicolumn{2}{|c|}{ Támogatott egészségipari tevékenység } & \multicolumn{2}{|r|}{ Támogatott vállalkozások } \\
\hline $\begin{array}{c}\text { a járványügyi védekezéssel } \\
\text { összefüggésben }\end{array}$ & jellege & $\begin{array}{l}\text { száma } \\
\text { (db) }\end{array}$ & $\begin{array}{c}\text { fötevékenysége a TEÁOR } \\
\text { besorolás alapján }\end{array}$ \\
\hline $\begin{array}{l}\text { Virusfertōzés megelözéséhez és } \\
\text { betegek kezeléséhez szükséges } \\
\text { gyógyszerek elöállitása }\end{array}$ & $\begin{array}{l}\text { termékgyártás, } \\
\text { modernizálás, } \\
\text { gyártókapacitás bövitése }\end{array}$ & 3 & $\begin{array}{l}\text { Gyógyszer, gyógyszerkészitmény } \\
\text { gyártása }\end{array}$ \\
\hline $\begin{array}{l}\text { Járványügyi védekezéshez } \\
\text { orvosi eszközök, müszerek } \\
\text { gyártása }\end{array}$ & $\begin{array}{l}\text { termékfejlesztés, } \\
\text { termékgyártás, } \\
\text { szervizelés }\end{array}$ & 6 & $\begin{array}{l}\text { Orvosi eszközök gyártása, javitása, } \\
\text { Fémfeldolgozás, } \\
\text { Gyógyszer, gyógyászati eszközök } \\
\text { nagykereskedelme, } \\
\text { Mérnöki tevékenység }\end{array}$ \\
\hline $\begin{array}{l}\text { Fertötlenitöszerekhez, higiénés } \\
\text { termékekhez, védőeszközökhöz } \\
\text { alapanyaggyártás }\end{array}$ & gyártókapacitás bövitése & 5 & $\begin{array}{l}\text { Élelmiszeripar, } \\
\text { Épitöanyag-nagykereskedelem, } \\
\text { Vegyiáru nagykereskedelem }\end{array}$ \\
\hline $\begin{array}{l}\text { Védelmi eszkōzök, fertōtlenítō- } \\
\text { szerek, speciális csomagoló- } \\
\text { anyagok gyártása }\end{array}$ & $\begin{array}{l}\text { termékfejlesztés, } \\
\text { termékgyártás, } \\
\text { gyártókapacitás bövitése }\end{array}$ & 5 & $\begin{array}{l}\text { Papíripar, } \\
\text { Fémipar, } \\
\text { Müanyagipar }\end{array}$ \\
\hline
\end{tabular}

1. táblázat

Az Egészségipari Támogatási Programban támogatott vállalkozások $(N=19)$ fö tevékenységük és a támogatás célja szerint, 2020 
ben is előfordul, hogy a fő profil mellett termelő tevékenységet is végeznek. Például az EU-FIRE Kft. olyan high-tech fém- és műanyageszközöket munkál meg, amelyeket azután az egészségiparban használnak. A kereskedelmi cégek közül a sárszentmihályi MASTERPLAST Kft. különböző egészségügyben használt higiéniai eszközök alapanyagát állítja elő a szájmaszkok és védőruhák gyártásán túl, miközben kapacitásait is bővíti a támogatásból. Szintén ezt tervezi megvalósítani a halásztelki MOLAR CHEMICALS Kft. a gyógyszeralapanyag-ellátás terén és a fertőtlenítőszer-gyártás érdekében. Ugyanakkor a KLIMEX Medical Kft. gyógyászati gázrendszerek, ágylámpasáv és nővérhívó rendszerek tervezéséhez, kiépítéséhez és szervizeléséhez kapott 540 millió forintos támogatást.

A nyertes ipari vállalkozások fő tevékenységének egy része közvetlenül kötődik az egészségiparhoz (pl. gyógyszergyártás), míg másik része közvetetten (pl. vegyi termékek gyártása). De ez utóbbiak már a támogatás előtt is foglalkoztak olyan termékek előálításával, amelyek az egészségipar számára is felhasználhatók. Például a fémipari tevékenység keretében kórházi berendezések, illetve eszközök (infúziótartó állványok, oxigénpalack-szállító kocsik stb.) előállítása (1. táblázat).

A vizsgált vállalkozások egy része arra is jó példát szolgáltat, hogy annak ellenére, hogy a fő tevékenységük nem kapcsolódik szorosan az egészségiparhoz, a járványügyi veszélyhelyzet kihívásaira mégis hatékonyan tudtak válaszolni a gyártókapacitás speciális átalakításával vagy bővítésével. Így például egyes élelmiszeripari tevékenységet folytató cégek nagyobb kapacitással álttak át a fertőtlenítőszerek alapanyagának gyártására. Egy papíriparban érdekelt vállalkozás pedig például higiénikus és csiramentesített zárt csomagolású maszkok gyártását indította el. A támogatás révén tehát olyan újszerű termelési tevékenységbe tudtak kezdeni, amelyek a profiljuk kiszélesedését és piaci helyzetük stabilizálását vagy további erősödését eredményezheti.

Az Egészségipari Támogatási Program keretében a 19 vállalkozás együttesen 24,3 milliárd Ft támogatást nyert el, ami a cégek közel fele számára csak néhány százmillió forintot jelentett. A legkisebb támogatási összeg 276 millió Ft volt, és a legnagyobb 7,5 milliárd Ft. Az előbbit kapacitásbővítésre tinktúra területén, modernizálásra és gyártókapacitások bővítésére adták, míg az utóbbit szájmaszkok, védőruhák és az egészségügyben használt higiéniai eszközök alapanyagának előállítására a kapacitásbővítés mellett. Általánosságban azt lehet mondani, hogy a kisebb, egy milliárd forint alatti támogatások főként kapacitásbővítést, üzemcsarnok-korszerűsítést, járványügyi védőeszközök gyártását célozták. Az ennél nagyobb volumenủ beruházások többek között lélegeztetőgépek és fertőtlenítő eszközök gyártására és/vagy kapacitásbővítésre, valamint a vírusfertőzés megelőzéséhez és a betegek kezeléséhez szükséges gyógyszerek előállítására, továbbá speciális maszkok, tabletták és fertőtlenítők csomagolására és veszélyes hulladéktárolók készítésére irányultak.

Az Egészségipari Támogatási Program által meghirdetett támogatási keretből az egyes pályázók különböző mértékben részesültek és a tervezett beruházások költségeinek eltérő hányadát fedezték. Akadt több olyan vállalkozás is (összesen öt), amelyeknek a projektjük teljes költségét a pályázati forrás biztosítja, de a legtöbbször az összköltség 70-80\%-át teszik ki a támogatások. A legkisebb hányadban (49\%) az egri székhelyű, orvosi műszereket gyártó Sanatmetál Kft. beruházását támogatták (1. ábra).

Az Egészségipari Támogatási Programban 2020 őszén támogatási forrást szerzett vállalkozások székhelye a legin-

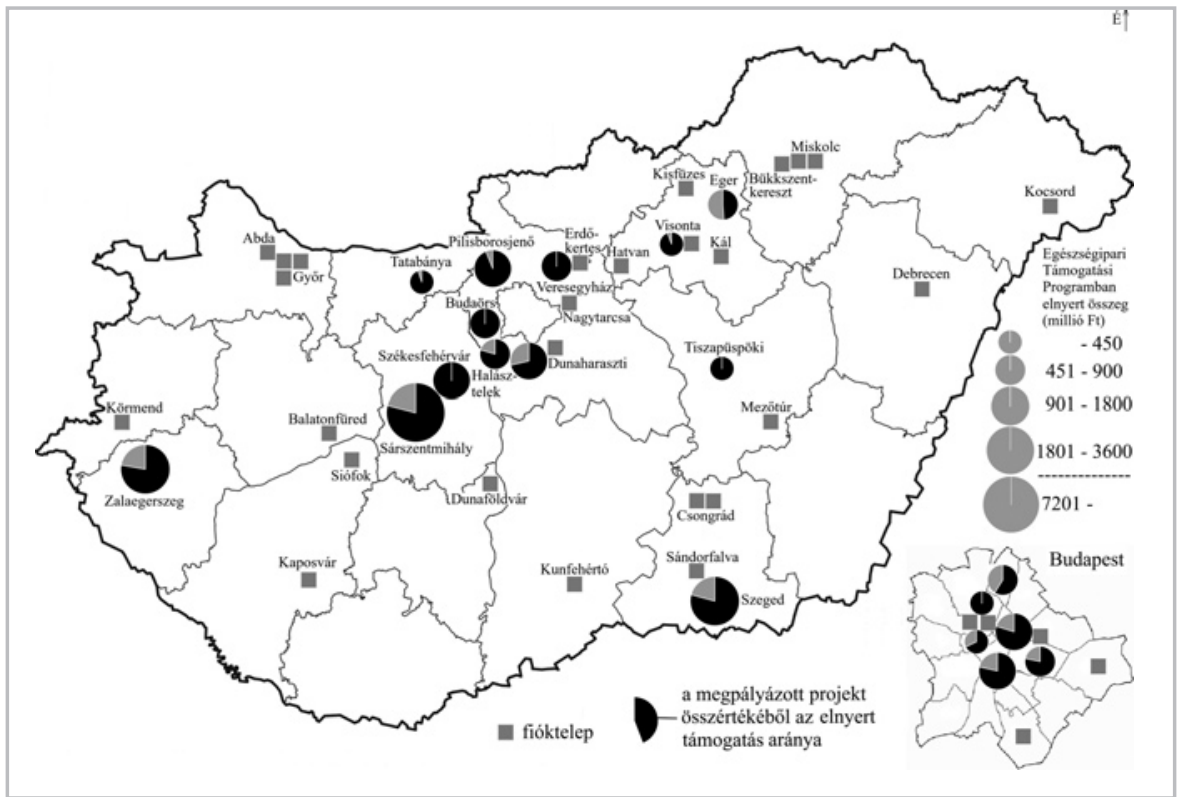

1. ábra

Az Egészségipari Támogatási Program által támogatott vállalkozások székhelye a támogatás összege és a beruházás értékéböl való részesedés alapján, valamint a fióktelepeik, 2020 
kább Budapesten és agglomerációjában, valamint a megyeszékhelyeken található. A vállalkozások telephelyeinek bemutatása azért is fontos, mert sok esetben a tényleges termelö, egészségipari tevékenység nem a székhelyen történik, hanem az azon kívüli telephelyeken vagy másképp fióktelepeken. Következésképp feltételezhető, hogy az elnyert támogatások is több-kevesebb mértékben a fióktelepeken kerülnek majd felhasználásra. Az is megfigyelhető, hogy amíg a székhelyek alapvetően városi jelenségek, addig a telephelyek körében már számottevőbb hányadot (38\%) képeznek a községek. A telephelyek területi eloszlásában nagyobb szóródás tapasztalható a székhelyek települési helyéhez képest. A központok és fióktelepek földrajza követi a magyar ipar térszerkezetét, elsődlegesen az ország északi felében tömörülnek, ahol az ipari tevékenység jelentősebb, és ahol az új, korszerübb infokommunikációs technológiák alkalmazása is jóval gyakoribb [14]. Az egészségipari vállalkozások területi megoszlása tehát hozzájárul a meglevő duális ipari térstruktúra fennmaradásához a negyedik ipari forradalom idején is.

\section{ÖSSZEFOGLALÁS}

Az egészségipar fejlesztése nemcsak gazdaságvédelmi szempontból fontos - különösen most a járvány idején hanem azért, mert az egészségügyi beruházások növelik az ellátásbiztonságot is. A 2020-ban meghirdetett Egészségipari Támogatási Program számottevően hozzájárul a támogatott hazai egészségipari vállalkozások megerősödéséhez és termelési kapacitásuk bővítéséhez, valamint új termékek technológiai fejlesztéséhez.

Az Egészségipari Támogatási Programból támogatott egészségipari vállalkozások többnyire hosszú múltra visszatekintő, középméretủ cégek, amelyek zömének a tevékenysége erőteljesen kötődött az egészségiparhoz már a koronavírus-járvány előtt is. Azt követően pedig a támogatások lehetőséget nyújtanak számukra a kapacitásbővítésre és/vagy új termékek kifejlesztésére, kiváltképp a gyógyszeripar területén. Az egészségipari beruházást végrehajtó vállalkozásokat markáns térbeli koncentráció jellemzi, mivel főleg az ország északi, iparosodottabb térségében találhatók, ahol az Ipar 4.0 technológiák is elterjedtebbek.

A vállalkozások többféle módon járulnak hozzá a hazai egészségipar fejlesztéséhez. A tervezett beruházásaikban bár elsőbbséget élvez a járványügyi védekezés és a járványnyal kapcsolatos újszerủ helyzetre való felkészülés és alkalmazkodás, mégis a megvalósítandó fejlesztések hosszú távon is támogatják az egészségipart és az egészségügyet. Többek között úgy, hogy kapacitásbővítéseikkel növelik az önellátást és/vagy az exportlehetőségeket. Az innováció révén új termékeket, új technológiákat vezetnek be. A támogatások elősegítik az ágazat technológia-intenzív fejlődését, a negyedik ipari forradalom vívmányainak terjedését, a $\mathrm{K}+\mathrm{F}$ feladatok elötérbe kerülését, továbbá a munkahelyteremtéssel a vállalkozások mérsékelhetik a foglalkoztatottsági egyenlőtlenségeket és végső soron mindezek a változások kedvezően hatnak nemcsak az egyes vállalkozások, hanem az egész ágazat versenyképességére.

Az Egészségipari Támogatási Program napjainkban is folytatódik, ami a kutatás folytatására sarkall, de a támogatások hasznosulásának a pontos felmérése is erre ösztönöz. 2021 tavaszán ugyanis még nem álltak rendelkezésre errő megbízható információk, mint ahogy arról sem, hogy közvetve vagy közvetlenül milyen Ipar 4.0 technológiai megoldások valósultak meg a támogatások hatására az egészségiparban. Éppen ezért a jövőben ezek jelentik majd a vizsgálódások fő irányait.

\section{KÖSZÖNETNYILVÁNÍTÁS}

A kutatás az Nemzeti Kutatási, Fejlesztési és Innovációs Hivatal által támogatott projekt (K125091) keretében valósult meg, amelyért a szerzök ezúton is köszönetüket fejezik ki.

\section{IRODALOMJEGYZÉK}

[1] Schwab K: The Fourth Industrial Revolution. CologneGeneva, World Economic Forum, 2016., 172 p.

[2] Bartodziej CJ: The Concept Industry 4.0. An Empirical Analysis of Technologies and Applications in Production Logistics, Berlin, Springer Gabler, 2017., 150 p. https://doi.org/10.1007/978-3-658-16502-4_5

[3] Állami Egészségügyi Ellátó Központ (ÁEEK): Egészségtudományi Fogalomtár. https://fogalomtar.aeek.hu/index.php/Eg\%C3\%A9szs\%C 3\%A9gipar [2021.01.19.]

[4] Kincses Gy: Az egészségipar társadalmi és nemzetgazdasági jelentősége, 2010., IME - Interdiszciplináris Magyar Egészségügy, IX. évfolyam 5. szám, 8-14. oldal

[5] Kansky JP: Managing the Business of Health Information Exchange, 2016., In: Dixon B E (ed.), Health Information Exchange, Elsevier, 77-89. oldal
https://doi.org/10.1016/B978-0-12-803135-3.00005-0

[6] Nemzeti Erőforrás Minisztérium: Gyógyuló Magyarország - Semmelweis Terv az egészségügy megmentésére, 2011., 133 oldal

[7] EMMI: Egészséges Magyarország 2014-2020 - Egészségügyi Ágazati Stratégia, 2015., 106 oldal

[8] DEFS - Digitális Egészségipar-fejlesztési Stratégia, 2017. https://digitalisjoletprogram.hu/hu/tartalom/defs-digitalisegeszsegipar-fejlesztesi-strategia [2021.01.16.]

[9] Szabó B: Újdonságok a koronavírus-járvány alatt az elektronikus egészségügyi szolgáltatások területén, 2020., IME - Interdiszciplináris Magyar Egészségügy, XIX. évfolyam 2. szám 33-34. oldal

[10] Tóth T, Palicz T, Szócska M: A magyar egészségügyi szakemberek digitális technológiákkal kapcsolatos attitủdjének vizsgálata, 2020., IME - Interdiszciplináris Ma- 
gyar Egészségügy, XIX. évfolyam 2. szám 44-47. oldal

[11] Geissbauer R, Vedso J, Schrauf S: Industry 4.0: building the digital enterprise. Global Industry 4.0. Survey. London, PwC. 2016.

https://www.pwc.com/gx/en/industries/industries-4.0/landing-page/industry-4.0-building-your-digital-enterpriseapril-2016.pdf [2021.01.16.]

[12] Sommer L: Industrial revolution-Industry 4.0: Are German manufacturing SMEs the first victims of this revolution? Journal of Industrial Engineering and Management, 2015. 8 (5) pp.1512-1532. https://doi.org/10.3926/jiem.1470

[13] Nagy Cs, Molnár E, Kiss É: Industry 4.0 in a dualistic manufacturing sector - qualitative experiences from enterprises and their environment, Eastern Hungary. Hungarian Geographical Bulletin, 2020. 69 (2) pp.157174. https://doi.org/10.15201/hungeobull.69.2.5

[14] Kiss É, Nedelka E: Geographical approach of Industry 4.0 based on information and communication technologies at Hungarian enterprises in connection with industrial space. Hungarian Geographical Bulletin, 2020. 69 (2) pp.99-117. https://doi.org/10.15201/hungeobull.69.2.2

\section{A SZERZŐK BEMUTATÁSA}
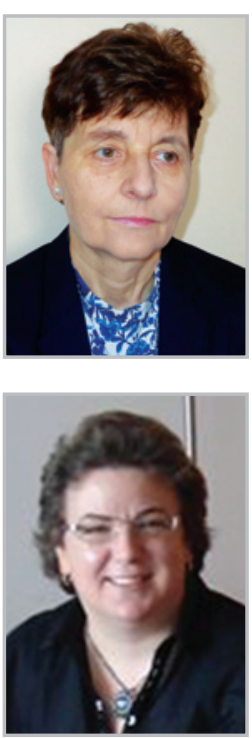

Dr. Kiss Éva tudományos tanácsadó a Csillagászati és Földtudományi Kutatóközpont Földrajztudományi Intézetében. 2008-tól az MTA Doktora, 2010-től egyetemi tanár. Tudományos kutatásainak középpontjában a magyar ipar

Dr. Uzzoli Annamária 1999-ben szerzett földrajztanári diplomát az Eötvös Loránd Tudományegyetem Természettudományi Karán. Doktori kutatásának témája az egészségi állapotban tapasztalható társadalmi-területi különbségek vizsgálata volt. PhD fokozatát 2004-ben területi folyamatainak vizsgálata áll, különös tekintettel a negyedik ipari forradalom térbeli összefüggéseire. Az IGU Commission on the Dynamics of Economic Spaces alelnöke és a Társadalomföldrajzi Tudományos Bizottság elnökhelyettese. Akadémiai díjas.

szerezte meg az Eötvös Loránd Tudományegyetemen. Egészségföldrajzi vizsgálataiban az egészségegyenlőtlenségek területi és földrajzi vonatkozásaival foglalkozik. Jelenleg a Csillagászati és Földtudományi Kutatóközpont Földrajztudományi Intézetében tudományos főmunkatárs. A Magyar Földrajzi Társaság Egészségföldrajzi Szakosztályának titkára.

\section{Semmelweis Egyetem
Közszolgálati
Kar}

A Semmelweis Egyetem egyik „legfiatalabb” kara 2010-ben alakult három, a természet- és társadalomtudományok határterületén dolgozó intézet részvételével:

\section{\Egészségügyi Menedzserképző Központ}

> Digitális Egészségtudományi Intézet

> Mentálhigiéné Intézet

Az alábbi területeken kínálunk lehetőséget

alap-és mesterképzés, felsőfokú szakképzés, doktori képzés, szakirányú továbbképzés, valamint rövidprogramok formájában:

> egészségügyi menedzsment >lelki és közösségi egészség

> egészségügyi informatika > szociális vezetőképzés

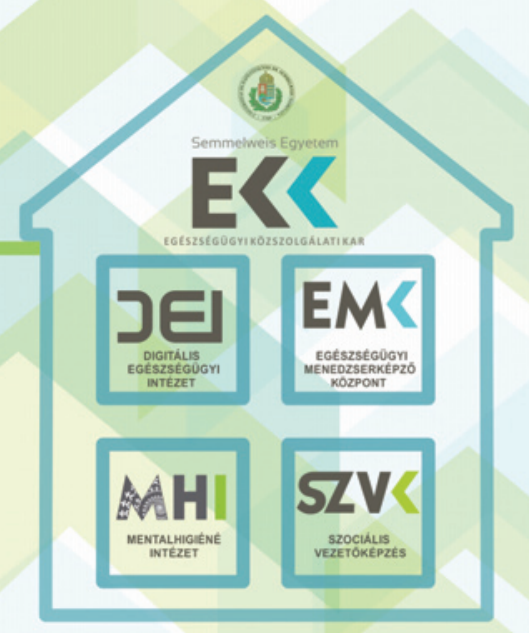

